\title{
Changes in Community-Level Riparian Plant Traits over Inundation Gradients, Colorado River, Grand Canyon
}

\author{
Miles E. McCoy-Sulentic ${ }^{1}$. Thomas E. Kolb ${ }^{1}$ - David M. Merritt ${ }^{2} \cdot$ Emily Palmquist $^{3}$. \\ Barbara E. Ralston ${ }^{4}$. Daniel A. Sarr ${ }^{3}$ • Patrick B. Shafroth ${ }^{5}$
}

Received: 10 November 2016/Accepted: 21 February 2017 / Published online: 17 March 2017

(C) The Author(s) 2017. This article is published with open access at Springerlink.com

\begin{abstract}
Comparisons of community-level functional traits across environmental gradients have potential for identifying links among plant characteristics, adaptations to stress and disturbance, and community assembly. We investigated community-level variation in specific leaf area (SLA), plant mature height, seed mass, stem specific gravity (SSG), relative cover of $\mathrm{C} 4$ species, and total plant cover over hydrologic zones and gradients in years 2013 and 2014 in the riparian plant community along the Colorado River in the Grand Canyon. Vegetation cover was lowest in the frequently inundated active channel zone, indicating constraints on plant establishment and production by flood disturbance and anaerobic stress. Changes in trait values over hydrologic zones and inundation gradients indicate that frequently inundated plots exhibit a community-level ruderal strategy with adaptation to submergence (high SLA and low SSG, height, seed mass, C4 relative cover), whereas less frequently inundated plots exhibit adaptation to drought and infrequent flood disturbance (low
\end{abstract}

Electronic supplementary material The online version of this article (doi:10.1007/s13157-017-0895-3) contains supplementary material, which is available to authorized users.

Thomas E. Kolb

Tom.kolb@nau.edu

1 School of Forestry, Northern Arizona University, Flagstaff, AZ, USA

2 USDA Forest Service, National Stream and Aquatic Ecology Center, Fort Collins, CO, USA

3 U.S. Geological Survey, Southwest Biological Science Center, Flagstaff, AZ, USA

4 U.S. Geological Survey, Office of Science Quality and Integrity, Flagstaff, AZ, USA

5 U.S. Geological Survey, Fort Collins Science Center, Fort Collins, CO, USA
SLA and high SSG, height, seed mass, C4 relative cover). Variation in traits not associated with inundation suggests niche differentiation and multiple modes of community assembly. The results enhance understanding of future responses of riparian communities of the Grand Canyon to anticipated drying and changes in hydrologic regime.

Keywords Plant functional trait · Wood density · Specific leaf area $\cdot$ Seed mass $\cdot$ Riparian $\cdot$ Regulated river $\cdot$ Stream flow . Stem specific gravity $\cdot \mathrm{C} 4$ photosynthesis

\section{Introduction}

Consideration of plant functional traits offers a promising approach for identifying links between plant characteristics, habitat conditions, and community assembly across environmental gradients and provides a functional complement to species and community analyses (Lavorel and Garnier 2002; Pywell et al. 2003; Wright et al. 2004; Bernhardt-Römermann et al. 2008; Merritt et al. 2010; Swenson and Weiser 2010; Sandel et al. 2011). Environmental filters are agents of selection on traits and thus affect site habitability for species (Grime 1977; Cornwell et al. 2006; Cornwell and Ackerly 2009). Theory and empirical evidence suggest that trait divergence is greatest at intermediate levels of disturbance and stress, and is lowest in the most stressful environments (Connell 1978; Fraser et al., 2016). Plant traits that are environmentally constrained have been hypothesized to vary consistently across environmental gradients (Messier et al. 2010; Shipley et al. 2016). Observations of low variance in plot-level traits despite high species turnover (Messier et al. 2010) and consistent changes in traits across environmental gradients (Wright et al. 2004; Chave et al. 2009) support this hypothesis. However, further studies are needed to investigate the extent to 
which relationships between traits and environmental gradients apply to specific regional and local contexts (Shipley et al. 2016).

In riparian ecosystems of arid regions, flow regime drives physiological drought and inundation stresses and physical flooding disturbance (Naiman et al. 1993; Lytle and Poff 2004; Stromberg et al. 2007). Gradients of disturbance and water availability strongly determine the composition and location of vegetation communities in riparian ecosystems (Pockman and Sperry 2000; Nilsson and Svedmark 2002; Sluis and Tandarich 2004). Plant communities change along these steep gradients, making riparian ecosystems in arid regions ideal for investigations of environmentally driven variation in plant functional traits.

Prediction of riparian community response to changes in inundation and water availability requires better understanding of relationships between plant community characteristics and environmental conditions (Merritt et al. 2010; HoughSnee et al. 2015). Vegetation encroachment, streamward expansion of xeric communities (terrestrialization), and reduced recruitment of some species commonly occur in riparian ecosystems of southwestern North America following changes to flow regimes (Turner and Karpiscak 1980; Shafroth et al. 2002; Merritt and Bateman 2012; Sankey et al. 2015). These changes strongly suggest that flooding and water stress influence riparian community-level traits (Kyle and Leishman 2009; Hough-Snee et al. 2015). A community-level trait is a metric calculated for an entire field plot from trait values of species that occur in the plot weighted by the relative abundance of species in the plot (Hollingsworth et al. 2013; Clark 2016). Comparisons of community-level traits over gradients provide understanding about environmental and plant functional controls over community assembly and ecosystem processes that may be transferable among systems.

Our study focuses on riparian vegetation of the Colorado River in Grand Canyon in semi-arid northern Arizona, where completion of Glen Canyon Dam in 1963 greatly reduced annual flood peaks, increased base flow and daily fluctuations, and altered sediment transport processes, which led to the establishment of riparian vegetation at lower elevations, extensive fluvial marsh formation, and expansion of vegetated fluvial surfaces (Turner and Karpiscak 1980; Stevens et al. 1995; Gloss et al. 2005; Sankey et al. 2015). A projected warmer future climate and changes in water availability in this region (Hayhoe et al. 2004; Seager et al. 2007; Seager and Vecchi 2010; Dominguez et al. 2012) may further alter river flow management and consequently affect riparian plant communities, especially those at the upper reaches of the floodplain through direct effects of climate. We investigated patterns in community plant cover and functional traits in two years $(2013,2014)$ along inundation gradients of the Colorado River in Grand Canyon. The inundation gradients were based on two approaches: continuous inundation duration, and three hydrologic zones based on historical inundation since dam control of river flow. Our study addressed the following questions: 1) How does plant cover vary over hydrologic zones (active channel, active floodplain, inactive floodplain)? 2) How do community-level traits vary over hydrologic zones? 3) How do community-level traits vary across a gradient of inundation? and 4) How are community-level traits intercorrelated? We used traits included in Westoby's L-H-S scheme (specific leaf area, height, seed mass; Westoby 1998) and Chave's wood economics spectrum (stem specific gravity; Chave et al. 2009), as well as photosynthetic pathway (Doliner and Jolliffe 1979; Sage 2004). We hypothesized that community-level traits would display a coordinated, functionally coherent shift from traits commonly associated with anaerobic tolerance, frequent disturbance and a ruderal strategy (i.e., high SLA, low height, low seed mass and SSG) in plots and zones that were frequently inundated to traits associated with drought tolerance and infrequent disturbance (i.e., lower SLA, greater SSG, height and seed mass) in less frequently inundated plots and zones.

\section{Methods}

\section{Site Description}

Our study area is $362 \mathrm{~km}$ of the Colorado River between Lees Ferry and Diamond Creek, AZ. This includes all of Marble Canyon and much of Grand Canyon (referred to collectively as Grand Canyon). Plant communities vary along the river, and are comprised of species found in the Great Basin, Sonoran, and Mojave Deserts, as well as numerous exotic species (McLaughlin 1986; Huisinga et al. 2006). Channel constrictions occurring at side canyons due to alluvial fans and debris create eddies and return flow hydraulic features that allow for deposition of sediments and formation of sandbars (Dolan et al. 1974; Howard and Dolan 1981; Schmidt 1990). Flooding has been greatly reduced, and variation in discharge has been largely controlled by dam operations since 1963 (Gloss et al. 2005), resulting in sharp gradients of inundation, scour and soil water availability across relatively short distances.

The river's margin can be segmented into three hydrologic zones based on flows controlled by Glen Canyon Dam (Department of Interior 1996): the active channel, active floodplain, and inactive floodplain (Ralston et al. 2014). The active channel (AC) is that portion of the shoreline that can experience daily inundation. The active floodplain (AF) experiences occasional inundation. The inactive floodplain (IF) is the portion of the historic floodplain that has not experienced inundation from dam operations since the exceptionally high runoff year in 1984 (Topping et al. 2003). Plant species occurrence and dominance vary across zones, though some common taxa occur across all three zones (Table 1). 
Table 1 Ten most frequent species in each hydrologic zone with proportional frequency of occurrence for that category in parentheses based on combined 2013 and 2014 data

\begin{tabular}{lll}
\hline Active Channel & Active Floodplain & Inactive Floodplain \\
\hline Salix exigua $(.23)$ & Pluchea sericea $(.40)$ & Pluchea sericea $(.37)$ \\
Pluchea sericea $(.15)$ & Tamarix spp. $(.30)$ & Tamarix spp. $(.33)$ \\
Baccharis emoryi $(.15)$ & Baccharis emoryi $(.21)$ & Bromus sp. $(.19)$ \\
Phragmites australis $(.14)$ & Salix exigua $(.20)$ & Bromus rubens $(.16)$ \\
Equisetum $x$ ferrissii $(.14)$ & Bromus rubens $(.13)$ & Sporobolus flexuousus $(.14)$ \\
Cynodon dactylon $(.08)$ & Bromus diandrus $(.13)$ & Acacia greggii $(.09)$ \\
Tamarix spp. $(.08)$ & Cynodon dactylon $(.10)$ & Prosopis glandulosa $(.08)$ \\
Polypogon viridis $(.07)$ & Equisetum x ferrissii $(.09)$ & Brickellia longifolia $(.07)$ \\
Schedonorous arundinaceus $(.07)$ & Sporobolus flexuosus $(.08)$ & Stephanomeria pauciflora $(.06)$ \\
\hline
\end{tabular}

\section{Plant Community Data}

Vegetation data were collected in late September 2013 and 2014. Surveys of 42 sandbar sites were conducted each year between 4 and $362 \mathrm{~km}$ downstream from Lees Ferry, AZ. Plot locations at each site were randomly selected each year. Three or four transects with 6 to $91-\mathrm{m}^{2}$ plots each were placed at each site based on sandbar size and shape, resulting in 24 to 36 plots surveyed per sandbar site each year. Each transect started at the water's edge and extended upslope perpendicular to the river, allowing for representation of all three hydrologic zones. Hydrologic zone designations for each plot were determined by examining modeled shorelines based on flows (Magirl et al. 2008) and the surveyed locations of each plot in ArcGIS version 10.3.1. An effort was made to include each hydrologic zone in all transects. Exceptions occurred when banks were steep, sandbars were small, or canyon topography prevented representation of each hydrologic zone. The aerial cover of each plant species within each $1-\mathrm{m}^{2}$ plot was visually estimated by trained observers as a percentage of the plot area. Elevation of each plot was surveyed with optical Topcon total stations (Topcon Positioning Systems, Inc.) located on geodetic control network benchmarks (Hazel et al. 2007).

\section{Trait Data}

We measured five traits included in Westoby's (1998) L-H-S scheme (specific leaf area, height, seed mass), Chave et al.'s (2009) wood economics spectrum (stem specific gravity), and photosynthetic pathway (Doliner and Jolliffe 1979; Sage 2004). Westoby's L-H-S scheme postulates that the three traits of SLA, plant maximum height, and seed mass represent the major axes of plant functional strategies (Westoby 1998, Weiher et al. 1999). High SLA often occurs in more physiologically active but shorter-lived leaves and in ruderal species (Grime 1977; Wright et al. 2004; Poorter and Bongers 2006). High SLA facilitates leaf gas exchange and plant growth and survival during submergence (Voesenek et al. 2006; Mommer et al. 2007). Mature plant height is related to competitive ability for light and perhaps soil resources based on the assumption that tall plants require more roots (Westoby 1998). Seed mass is a reproductive trait that often varies across environmental gradients (Grubb 1977; Guo et al. 2000; Hampe 2004). Species with small seed mass typically produce a larger number of seeds which are more widely dispersed than species with large seeds (Westoby et al. 1992). These same smallseeded species tend to be less dominant at dry sites because large seeds facilitate establishment on stressful sites (Westoby et al. 1992; Leishman et al. 1995; Larios et al. 2014).

Stem specific gravity (SSG) is a key trait in the wood economics spectrum, which is a framework for understanding adaptation and tradeoffs in stem traits of woody plants (Chave et al. 2009). Plants with dense wood may be more resistant to xylem cavitation, thus are well adapted to drought compared to species with porous, low density wood (Pockman and Sperry 2000; Hacke et al. 2001; Chave et al. 2009). Our study extends the use of SSG beyond woody plants to herbaceous plants, in which cavitation resistance also has been associated with stem tissue density (Wahl and Ryer 2000; Lens et al. 2016). Also, we investigated plot coverage by species with the $\mathrm{C} 4$ photosynthetic pathway, which are mostly grasses in our study, because the $\mathrm{C} 4$ pathway confers greater photosynthetic rate and water use efficiency in semiarid areas with high irradiance and mean temperature (Doliner and Jolliffe 1979; Teeri and Stowe 1976; Kemp 1983).

We included total plant cover in our study to better understand limitations to plant establishment and production by hydrological conditions. Disturbance and abiotic stress are well-known limitations on plant cover (Grime 1977; Stromberg et al. 2007). In our study of riparian vegetation in Grand Canyon, the primary disturbances are shear stress, scouring, abrasion, and burial from deposition during floods, and the primary abiotic stresses include seasonal submergence and inundated anaerobic soils near the river, and drought stress at more upland sites within the river corridor (Howard and Dolan 1981; Stevens et al. 1995; Sankey et al. 2015).

Data from the 2013-2014 plant sampling (above) were used to guide selection of species for community-level 
calculations and analyses. We measured or compiled data for 107 species, which include all species that were most commonly documented in the 2013 and 2014 surveys, as well as many less common species.

Height, seed mass, and photosynthetic pathway were obtained from previously compiled databases and floras (e.g., Welsh et al. 2003; Baldwin 2002) and prior publications as described in Palmquist et al. (2017) (Table 2). Plant heights at maturity were compiled from floral descriptions (Table 2). Seed mass data were compiled from the KEW Royal Botanic Garden Seed Information Database (Royal Botanic Gardens Kew 2016, http://data.kew.org/sid/), and consist of average weight in grams per 1000 seeds. Photosynthetic pathways ( $\mathrm{C} 3$ or $\mathrm{C} 4)$ were not found for all species, but if another species in the same genus was available, we assumed the same pathway for the species of interest (Syvertsen et al. 1976; Doliner and Jolliffe 1979; Waller and Lewis 1979; Boutton et al. 1980).

We collected plant tissue for measurements of SLA and SSG because data on these traits are not available for many species we investigated. Collection of plant tissue along the Colorado River took place during fall 2014 and 2015 (84\% of species), along the upper Verde River, as well as the vicinity of Flagstaff, AZ during summer 2015 (16\% of species). Collection sites along the upper Verde River (a smaller order stream in northern Arizona sharing many species with Grand Canyon) were approximately $130 \mathrm{~km}$ south of Grand Canyon; Flagstaff, AZ, is approximately $100 \mathrm{~km}$ SSE of Grand Canyon. Collection outside of Grand Canyon was occasionally done due to difficulties in accessing the inner Grand Canyon to sample certain species, and based on current understanding that species rankings of trait values are conserved across spatial scales (e.g., within-species variance in traits is much lower than among-species variance) (Kazakou et al. 2014; Ordonez 2014). Five individuals from one representative population of each species were sampled and used to estimate species mean values of traits (Kazakou et al. 2014; Ordonez 2014). We maximized the trade-off between number of species, time for sample preparation and analysis, and number of individuals per species, concluding that five samples per species would well-represent the dominant species in our study of over 100 species. We targeted individuals within the population that were mature, healthy, and were in locations typical for the species (PérezHarguindeguy et al. 2013). We did not sample species located in suboptimal habitat or with visible signs of water stress, disease or insect or herbivore damage. Plant tissue collected in the field was kept in sealed plastic bags with a damp paper towel inside coolers with ice during collection trips and transportation back to the laboratory. Once returned, samples were kept cool at $2-6^{\circ} \mathrm{C}$ until measurements were made.

Specific leaf area $\left(\mathrm{cm}^{2} \mathrm{~g}^{-1}\right)$ was measured on four fully developed leaves from each of five individuals, and the individual plant averages were used to calculate a species average. Leaves were scanned using Winfolia software (V. 2007b, Regent Instruments, Inc.) to determine leaf area, then oven dried at $70{ }^{\circ} \mathrm{C}$ for $72 \mathrm{~h}$ and weighed to determine mass. Petioles were included in measurements of SLA. Exceptions to this protocol included species of Tamarix, Ephedra, Equisetum, and Juncus. For Tamarix sp., a heavily foliated branchlet located near the end of a branch was used rather than an individual leaf scale. For species of Ephedra, Equisetum, and Juncus, a photosynthetic stem segment was used (variable length depending on species).

Tissue used in measurements of SSG $\left(\mathrm{g} \mathrm{cm}^{-3}\right)$ for woody shrubs and herbaceous species consisted of whole stem crosssections from the base of the stem, about $5 \mathrm{~cm}$ in length. Exceptions to this protocol included species of Equisetum, Juncus and Plantago, for which the base of the leaf was used as a stem segment. Measurements for trees were made on both sapwood obtained from increment cores and one branch crosssection, and the average of the two values was used. For the six tree species sampled (Acacia greggii, Prosopis glandulosa, Populus fremontii, Celtis laevigata, Tamarix sp., Salix gooddingii) only Celtis laevigata had a significant difference in SSG between cores and branch cross sections $(t=4.1488$, $p=0.003)$. Measurement of SSG followed the water displacement method (Williamson and Wiemann 2010). Herbaceous stems were dried at $70{ }^{\circ} \mathrm{C}$ for $72 \mathrm{~h}$ (Pérez-Harguindeguy et al.
Table 2 Summary of trait data collected

\begin{tabular}{lll}
\hline Trait & Description (unit) & Source \\
\hline $\begin{array}{l}\text { Specific leaf area } \\
\text { Plant height }\end{array}$ & Continuous $\left(\mathrm{cm}^{2} \mathrm{~g}^{-1}\right)$ & Field measurements \\
& Continuous (meters) & Flora of North America (1993), \\
& & Jepson Desert Manual (Baldwin 2002), \\
& A Utah Flora (Welsh et al. 2003) \\
Seed mass & Kewtinuous (g per 1000 seeds) & Koyalaba Botanic Gardens \\
& & Kew 2016, http:/data.kew.org/sid/) \\
Stem specific gravity & Continuous $\left(\mathrm{g} \mathrm{cm}^{-3}\right)$ & Field measurements \\
Photosynthetic pathway & Categorical $(\mathrm{C} 3$ or C4) & Published literature \\
Total cover & Continuous $(\%)$ & Field measurements \\
\hline
\end{tabular}


2013) and woody stems were dried at $103{ }^{\circ} \mathrm{C}$ for $72 \mathrm{~h}$ (Williamson and Wiemann 2010) before measurement of mass.

\section{Community-Level Traits}

A community-level value was calculated for each trait in each plot using two matrices of primary data (Hollingsworth et al. 2013; Clark 2016). A matrix of relative species cover within each $1-\mathrm{m}^{2}$ plot was calculated by dividing each species cover by the total vegetation cover of the plot. A second matrix of the average trait value for each species was multiplied by the relative cover matrix, and then summed over all species in the plot to produce a community-level trait value for the plot. This community-level trait expresses the traits of all species (woody and herbaceous) in each plot as a single value, which was used as data in subsequent ANOVA and regression analyses (see below). The inclusion of both herbaceous and woody species in this metric allowed us to compare community-level traits over inundation and hydrological gradients which included frequently inundated plots dominated by herbaceous species and less-frequently inundated plots dominated by woody species.

\section{Inundation Metric}

We calculated several metrics of inundation for each plot based on stage discharge relationships (Hazel et al. 2007), with inundation defined as elevation of river stage greater than the surveyed plot elevation. We calculated average yearly inundation duration (hours) for both the entire calendar year and traditionally defined growing season (April-September), the cumulative hours of inundation for both the entire year and growing season, and the maximum continuous period of inundation during the entire period (2007-2014). These measures of inundation were all strongly correlated (Spearman rank correlations $\left(r_{s}\right) \geq 0.86$, $p<0.001$ ) with each other as well as with the exceedance probability (probability that stage height will exceed plot height) calculated for the 2013 survey plots based on the 1984-2013 streamflow record (Paul Grams, U.S. Geological Survey (USGS), pers. comm.). We used average yearly inundation duration in our analyses because it is easy to understand and is highly associated with other inundation metrics. Our calculation of inundation for plots based on stage-discharge relationships from data collected prior to 2008 (Hazel et al. 2007) may have some limitations due to recent changes in sand bar morphology during experimental high flow releases from Glen Canyon Dam in 2008, 2012, and 2013, but they are the best and most recent stage-discharge relationships we have.

\section{Data Analysis}

For analyses of community-level traits, we used only plots for which we could account for $90 \%$ or more of the vegetation cover with trait values. Bare plots with no cover were removed from analysis of community traits, but were included for analysis of total cover. This data selection protocol resulted in 625 and 698 plots for analysis of community traits, and 944 and 976 plots for analysis of total cover, for 2013 and 2014, respectively.

For total plant cover and $\mathrm{C} 4$ cover, which had highly skewed distributions, we pooled data over years and used Kruskall-Wallis analysis to test for overall differences among the six combinations of zone and year, and Wilcoxon rank sum comparisons to test for pairwise differences. Community trait values, except SSG, were transformed as needed to stabilize residuals and comply with normality assumptions (SLA (square-root transformed)), height $(\ln (\mathrm{x}=1)$ transformed $)$, seed mass (ln transformed). Then, data were pooled over years and analyzed with linear mixed models with the zone, year, and the zone $x$ year interaction as fixed effects, and site and transect nested within site as random effects to account for our measurement of species cover over 46 sites with multiple transects per site. Zone, year, and their interaction were considered fixed effects to facilitate direct statistical tests of the effect of zone and impacts of different years on zone differences. All community-level traits had significant $(p<0.05)$ zone $\mathrm{x}$ year interactions. Zone $\mathrm{x}$ year least-square means from the model were compared with Tukey H-D comparisons, and then back-transformed to the original scale for display in the figures.

Our second analysis approach characterized the relationship between community-level traits and a continuous gradient of plot-level inundation duration. We used linear mixed models with year, inundation duration, and inundation $\mathrm{x}$ year interaction terms as fixed effects, and site and transect nested within site as random effects. Dependent data were transformed as described above, except that seed mass was power-transformed using the Box-Cox procedure (Box and Cox 1964). Inundation duration was $\log 10$ transformed to help meet model assumptions. Conditional predicted values from the model, which account for all fixed and random effects, were plotted and regressed against inundation to display the direction and strength of the relationship between trait values and inundation. These plots use the transformed units to preserve the linear architecture of the models. For these analyses we used plots with at least one hour of inundation over the analysis period (2007-2014) to remove zeros and to focus the analysis to landscape areas that have the potential for exposure to flooding under contemporary conditions $(n=169$ in 2013, $n=154$ in 2014). C4 cover was not included in these analyses because of small sample size $(n<54)$ for plots with at least one hour of inundation. All analyses were done using JMP statistical software (JMP®, Version Pro 13).

The datasets generated during and/or analyzed during the current study are available in the ScienceBase repository, http://dx. doi.org/10.5066/F73R0R24 (McCoy-Sulentic et al. 2017). 

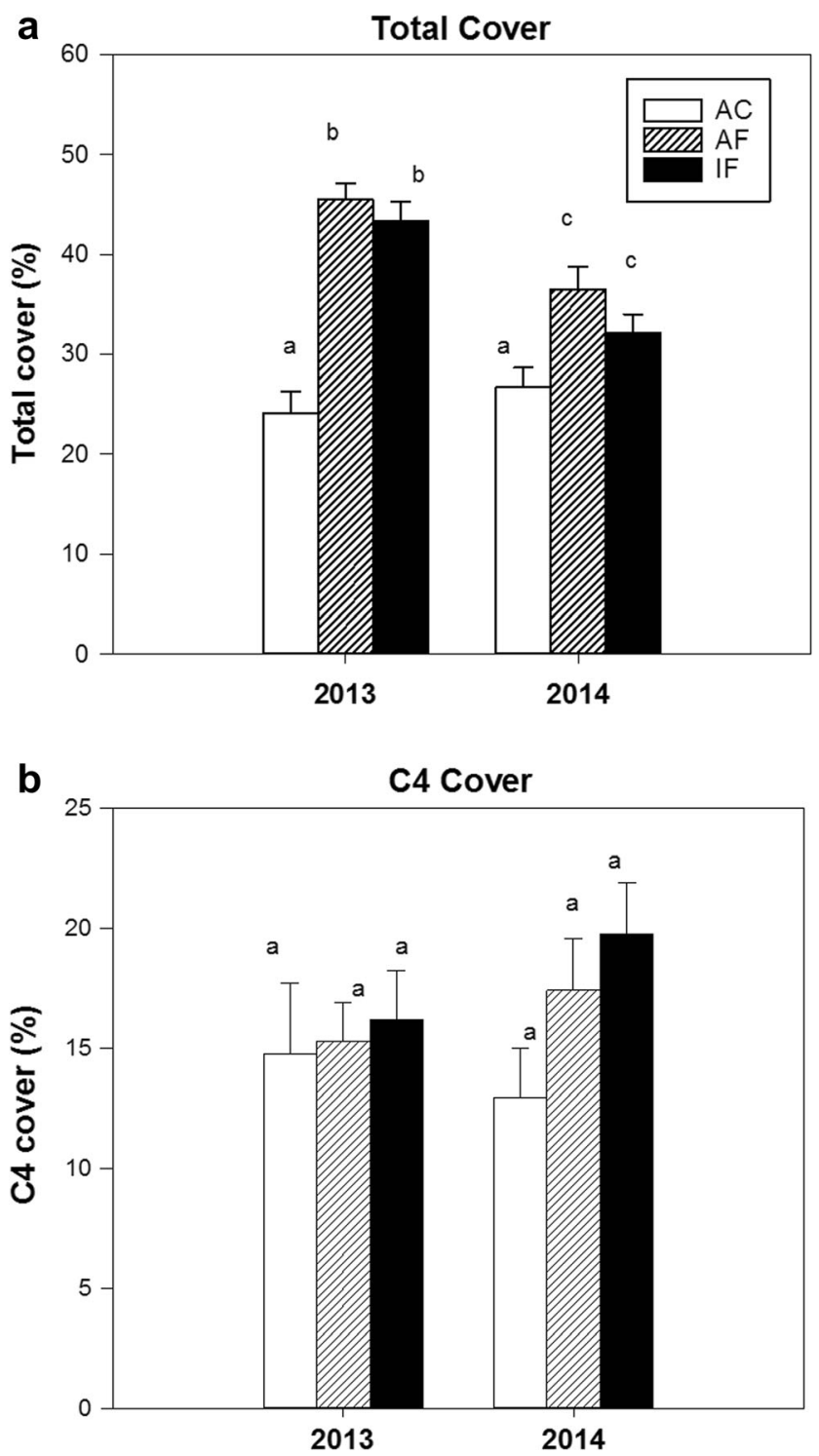

Fig. 1 Comparison of total plant cover and $\mathrm{C} 4$ cover among hydrologic zones $(\mathrm{AC}=$ active channel, $\mathrm{AF}=$ active floodplain, $\mathrm{IF}=$ inactive floodplain) and years (2013, 2014). Different letters denote significant differences over zones and years based on Wilcoxon rank sum comparisons at $p<0.05$. Error bars represent one standard error of the mean

\section{Results}

\section{Total and C4 Cover}

A highly significant $(p<0.0001)$ Kruskal-Wallis chi-squared test indicated large differences in total plant cover over combinations of zone and year. In both 2013 and 2014, the active channel had significantly lower total plant cover than both the active floodplain and inactive floodplain (Fig. 1a). Total cover was greater in both the active floodplain and inactive floodplain in 2013 than in 2014.

Differences among zones and years for cover of species with the $\mathrm{C} 4$ photosynthetic pathway were weaker (Kruskal-
Wallis chi-squared test $p=0.067$ ) than for total cover. Wilcoxon rank sum comparisons showed no significant differences in $\mathrm{C} 4$ cover among zone by year values, but $\mathrm{C} 4$ cover tended to increase from the active channel zone to the inactive floodplain zone in 2014 (Fig. 1b).

\section{Specific Leaf Area}

Community-level SLA was significantly influenced by zone $(p<0.0001)$, year $(p=0.0008)$, and the zone $\mathrm{x}$ year interaction $(p<0.0001)$. SLA was lower in the active floodplain and inactive floodplain zones than the active channel in 2013 (Fig. 2a). Zones had similar SLA in 2014 (Fig. 2a). In the continuous regression analysis, inundation $(p<0.0001)$, year $(p<0.0001)$, and the inundation $\mathrm{x}$ year interaction $(p=0.044)$ were significant sources of variation in SLA, and the overall model explained $29 \%$ of variation. SLA increased with inundation (Fig. 2a), with a greater increase in 2013 than 2014 (inset Fig. 2a).

\section{Height}

Community-level height was significantly influenced by zone $(p<0.0001)$, year $(p=0.027)$, and the zone $\mathrm{x}$ year interaction $(p<0.037)$. Height increased from the active channel to more arid zones in both years, with significant differences in 2013 (Fig. 2b). Inundation was the only significant fixed effect on height in the continuous regression analysis $(p<0.0001)$, which explained $30 \%$ of total variation. Height decreased with inundation duration (Fig. 3b).

\section{Seed Mass}

Community-level height was significantly influenced by zone $(p<0.0001)$, year $(p=0.020)$, and the zone $\mathrm{x}$ year interaction $(p=0.003)$. In both years, seed mass increased significantly from the active channel to the active floodplain. Inundation was the only significant fixed effect on seed mass in the continuous regression analysis $(p<0.0001)$, which explained $39 \%$ of total variation. Seed mass decreased with inundation duration (Fig. 3c).

\section{Stem Specific Gravity}

Community-level SSG was significantly influenced by zone $(p<0.0001)$, the zone $\mathrm{x}$ year interaction $(p<0.0001)$, but not year $(p=0.164)$. SSG increased significantly from the active channel to the active floodplain zone and then again to the inactive floodplain zone in both years (Fig. 2d). Inundation was the only significant fixed effect on SSG in the continuous regression analysis $(p<0.0001)$, which explained $37 \%$ of total variation. SSG decreased with inundation duration (Fig. 3d). 
Fig. 2 Comparison of community-level mean specific leaf area (SLA), height, seed mass, and stem specific gravity (SSG) among hydrologic zones $(\mathrm{AC}=$ active channel, $\mathrm{AF}=$ active floodplain, IF = inactive floodplain) and years $(2013,2014)$. Different letters denote significant differences over zones and years based on Tukey H-D pairwise comparisons at $p<0.05$. Error bars represent one standard error of the mean. Values of specific leaf area, height, and seed mass are back-transformations to original units; stem specific gravity was not transformed
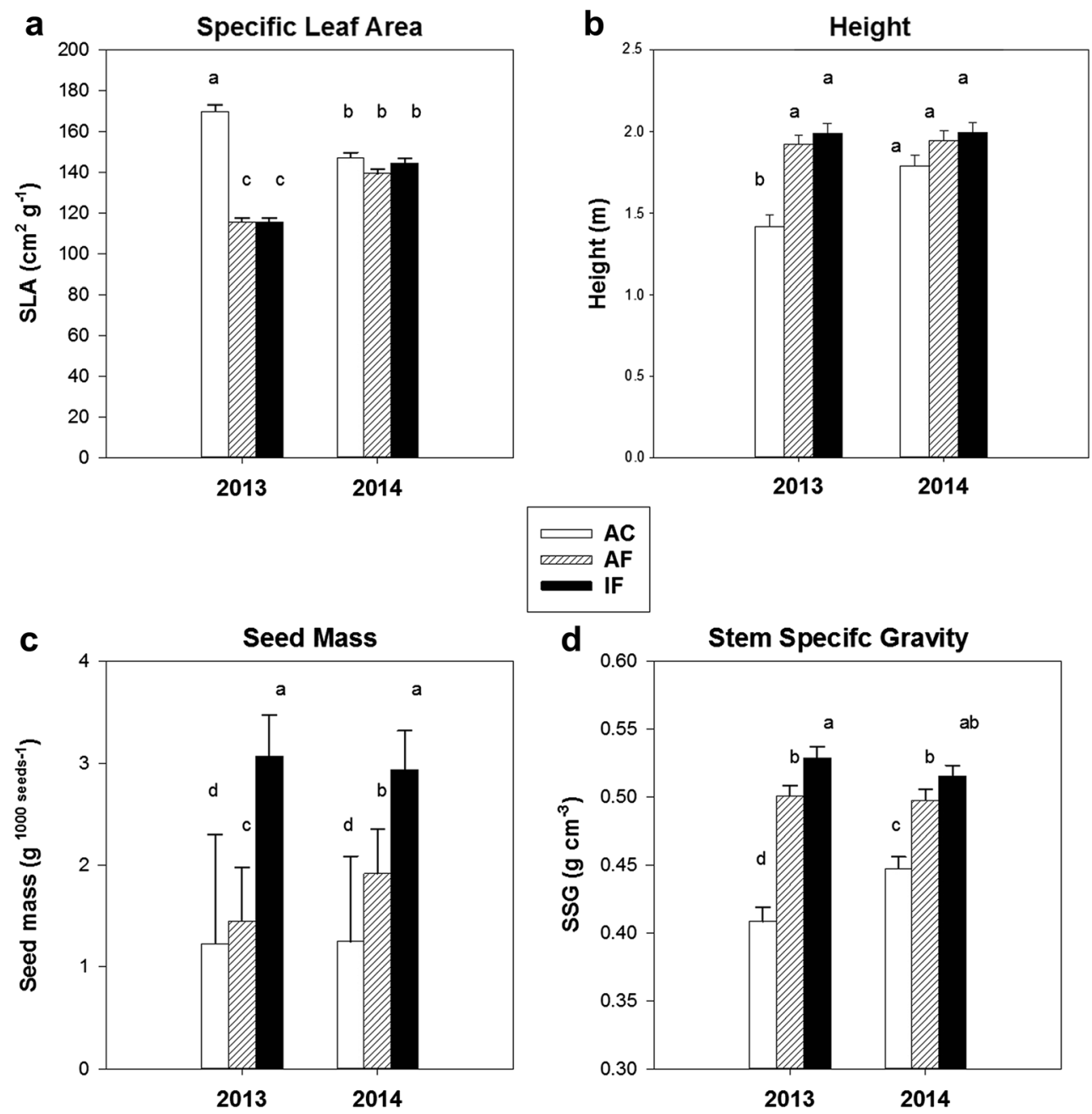

\section{Correlation among Traits}

Rank correlations were significant among many traits (Table 3). SLA was most strongly correlated with height in both years $\left(r_{\mathrm{s}}=-0.62,-0.41\right.$, in 2013 and 2014, respectively), moderately correlated with SSG ( -0.48 , $-0.27)$ and $\mathrm{C} 4$ cover $(-0.48,-0.27)$, and weakly correlated with seed mass $(0.04,0.11)$. Additionally, height was most strongly correlated with SSG $(0.51,0.50)$ and then $\mathrm{C} 4$ cover $(-0.5,-0.44)$.

\section{Discussion}

Our study provides a unique evaluation of the influence of hydrologic stress and disturbance on riparian plant community functional traits over a large arid region where a highly regulated river flows through one of the deepest canyons on earth. The sites feature distinct hydrologic zones, large inter-annual variation in precipitation, and mixtures of native and exotic and herbaceous and woody plants. Substantial variation in community composition and traits occurred in our sampling over two consecutive years, among 42 sites dispersed over $226 \mathrm{~km}$ of river length, and among transects within a site. Other limitations to our study include reliance on regional databases for data on some traits (seed mass, mature height, photosynthetic pathway), empirical measurements of other traits (SLA, SSG) in only one population per species (usually at a study site), numerous small size plots $\left(1 \mathrm{~m}^{2}\right)$ that maximized spatial replication but may have compromised measurement of larger-scale community composition, and empirical measurements of community composition only in late summer and in only two years. Despite these limitations, we found strong evidence, using mixed models that accounted for sampling variation, for influences on riparian community plant cover and functional traits by hydrological conditions along the Colorado River in Grand Canyon. The results support our overall hypothesis of a shift in community-level traits from zones that are frequently inundated to zones that are less frequently inundated. 
Fig. 3 The importance of inundation to traits is shown by relationships between average annual inundation duration and mixed model-predicted community-level trait values, which include both fixed effects (year, inundation, inundation $x$ year interaction) and random sampling effects (site, transect within site). Inset in panel a shows a significant interaction between inundation x year for specific leaf area; interactions not significant for other traits. Gray band shows the $95 \%$ confidence interval of the linear regression
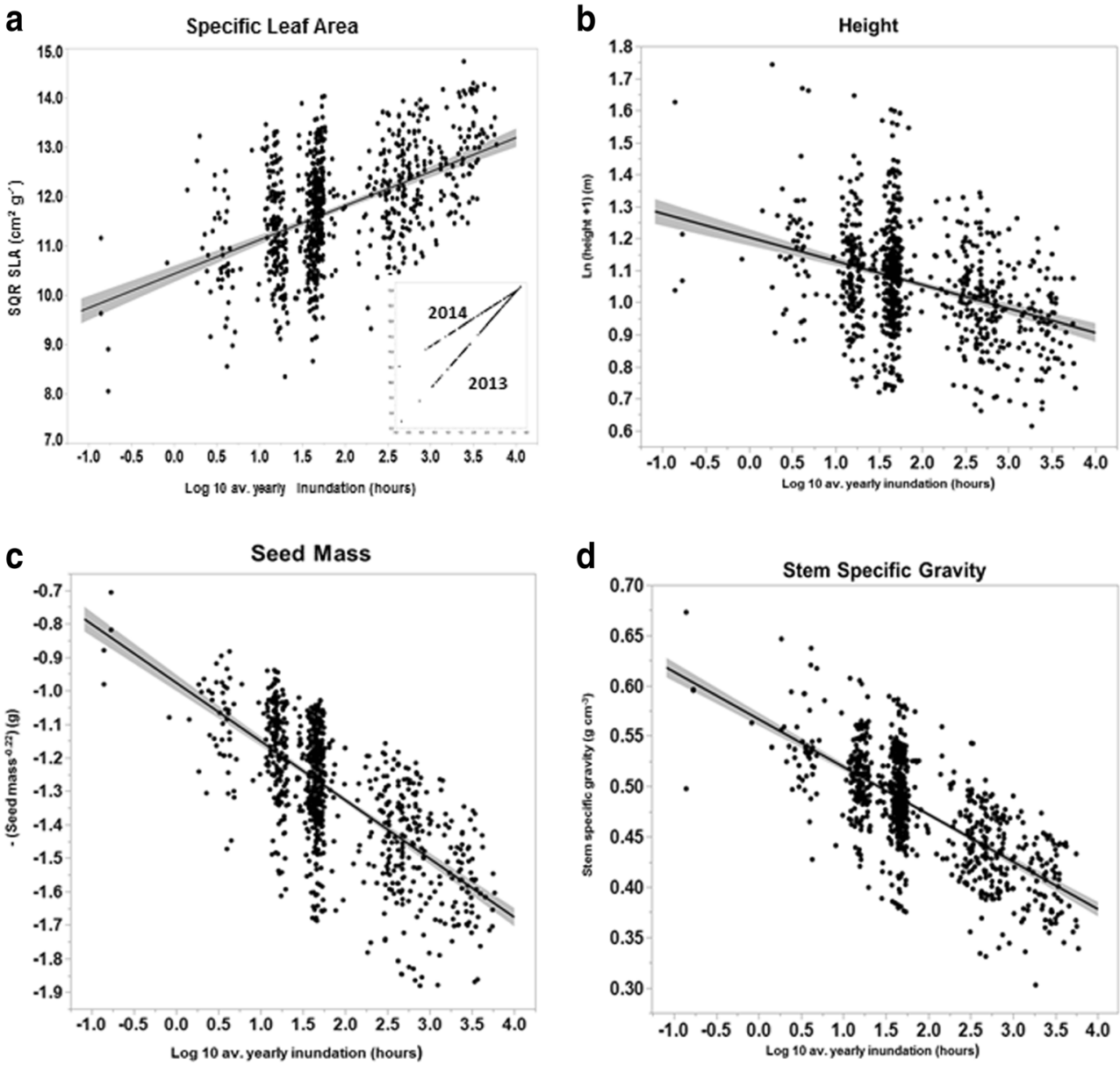

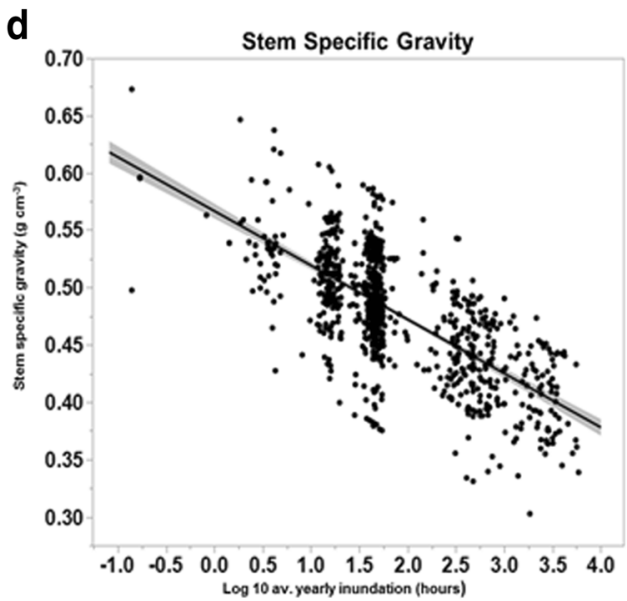

\section{Total and C4 Cover}

Our finding that total plant cover was lowest in the frequently inundated active channel (Fig. 1a) corroborates welldocumented constraints to plant establishment and production from a combination of frequent scouring, silt deposition, and anaerobic soil conditions. Sparse community-level plant

Table 3 Spearman rank correlations among community-level traits for 2013 and 2014. Significance level indicated by $*=p \leq 0.05, * *=p \leq 0.01$

\begin{tabular}{lllll}
\hline 2013 & SLA & Height & Seed & SSG \\
\hline Height & $-0.62 * *$ & & & \\
Seed & 0.04 & $-0.12 * *$ & & \\
SSG & $-0.48 * *$ & $0.51 * *$ & $0.14 * *$ & \\
C4 Cover & $0.49 * *$ & $-0.50 * *$ & 0.06 & 0.02 \\
2014 & & & & \\
Height & $-0.41 * *$ & & & \\
Seed & $0.11 * *$ & $-0.23 * *$ & & \\
SSG & $-0.27 * *$ & $0.50 * *$ & 0.06 & -0.02 \\
C4 Cover & $0.40 * *$ & $-0.44 * *$ & $0.10 * *$ & \\
\hline
\end{tabular}

cover, short height, and high SLA in the active channel zone are consistent with dominance by short-lived ruderal species adapted to tolerating frequent disturbance and to avoiders of such disturbance (e.g, annuals) (Grime, 1977, 1979). Plant cover in the two higher elevation zones (active floodplain, inactive floodplain) was about $50 \%$ greater than in the active channel in 2013 and about $20 \%$ greater in 2014, indicative of less frequent flooding disturbance at higher elevations.

Our results for total cover provide a framework for interpreting differences in traits among hydrologic zones and inundation gradients. Community traits of plants in the active channel and frequently inundated plots reflect dominance of species adapted to tolerating or avoiding flooding, traits distinctive to the active floodplain and moderately inundated plots reflect dominance of species adapted to intermediate disturbance and stress, and traits distinctive to the inactive floodplain reflect dominance of species adapted to drought stress and infrequent disturbance.

We found a weak $(p=0.067)$ trend of increasing C4 cover from the active channel to the more arid inactive floodplain (Fig. 1b), consistent with expectations given the physiological advantages of C4 species on hot, dry sites (Doliner and Jolliffe 1979; Teeri and Stowe 1976; Kemp 1983). The increase in C4 
cover from wet to dry zones was more pronounced in 2014 than 2013. One potential explanation for differences in total and $C 4$ cover among zones in 2013 and 2014 is the additional $127 \mathrm{~mm}$ of precipitation that fell in the inner Grand Canyon in 2013 (268 $\mathrm{mm}$ in $2013 \mathrm{vs} 141 \mathrm{~mm}$ in 2014, Phantom Ranch Weather Station USC00026471), and the subsequent higher river levels measured during the growing season in 2013 (Supplementary Materials). The combination of greater precipitation and river level in 2013 likely alleviated drought stress on vegetation growing in zones above the active channel. Because shallow-rooted plants in more upland zones are more strongly influenced by precipitation than plants in the active channel zone (Sankey et al. 2015), drier conditions in upland zones in 2014 should have given $\mathrm{C} 4$ species an advantage over C3 species.

\section{Specific Leaf Area}

Community SLA differed significantly among hydrologic zones for 2013 community data (Fig. 2a), with the same nonsignificant trend in 2014. Higher SLA in wetter hydrologic zones (Fig. 2a) and more inundated plots (Fig. 3a) are consistent with dominance of communities in the active channel by short-lived ruderal species that have an acquisitive leaf economic strategy (Diaz et al. 2016), and with the facilitation of leaf gas exchange and survival during submergence by high SLA (Voesenek et al. 2006; Mommer et al. 2007). Some obligate wetland species in our study, such as Typha spp., have low SLA (McCoy-Sulentic et al. 2017, written communication), but these species represent only a small portion of the riparian community in the active channel along the Colorado River in Grand Canyon (Stevens et al. 1995), and thus had a small quantitative influence on plot-level community values of SLA in our study. High SLA in the active channel is due in part to dominance in this zone of exotic Bermuda grass (Cynodon dactylon), which has high SLA. Results from both the categorical zone (Fig. 2a) and continuous inundation (Fig. 3a) analyses show interannual variation in response of community SLA to inundation. Causes of this interannual variation likely include shifts in species relative dominance and phenological plasticity in SLA between dry and wet years.

\section{Height}

Community-level height was lowest in the wetter and more frequently inundated active channel zone (Fig. 2b) and decreased with inundation duration (Fig. 3b), and these patterns were fairly consistent over years. The increase in plant height from the active channel to drier, less-frequently inundated zones in our study is consistent with other studies of riparian ecosystems (Kyle and Leishman 2009). Tall community height in the inactive floodplain zone reflects greater dominance by perennial woody species with greater rooting depth allowing access to groundwater (Stromberg 2013), and whose establishment was facilitated by the longer intervals between flooding disturbance in this zone compared with zones located closer to the river.

\section{Seed Mass}

Our results for consistent changes in community seed mass over hydrologic zones (Fig. 2c) and continuous gradients of inundation (Fig. 3c) for both years are consistent with previous findings about distribution of seed mass over environmental gradients (Westoby et al. 1992; Westoby and Wright 2006). Smaller seed mass in the more frequently inundated active channel in our study strongly suggests production of a greater number of seeds, greater dispersal distance, and higher chances of seeds reaching and seedlings becoming established at freshly scoured sites (Stromberg et al. 2008; Kyle and Leishman 2009). Conversely, high seed mass in the inactive floodplain in our study likely facilitates seedling establishment and persistence in more arid, upland sites in the riparian zone, consistent with other studies of riparian ecosystems (Stromberg et al. 2008; Kyle and Leishman 2009).

\section{Stem Specific Gravity}

Our finding that community SSG increased from the active channel to inactive floodplain, and decreased over a continuous gradient of inundation duration in both years, is consistent with a functional role of SSG in adaptation to both extremely wet and dry environments. Low SSG in the wettest, most frequently inundated plots in our study is indicative of lowdensity stem aerenchyma tissue that facilitates oxygen transport to submerged plant tissues (Sorrell et al. 2000; Voesenek et al. 2006), and greater diameter xylem vessels that allow for greater water transport to support high leaf gas exchange (Ishida et al. 2008; Reich 2014). Conversely, high SSG in drier upland zones and plots in our study is indicative of greater xylem cavitation resistance (Pockman and Sperry 2000; Hacke et al. 2001; Preston et al. 2006; Chave et al. 2009). Our finding of a positive association between SSG and riparian zone aridity for communities containing a mixture of woody and herbaceous plants, as well as in separate analyses for herbaceous species (McCoy-Sulentic et al. 2017, written communication), strongly suggest a role of high SSG in adaptation of herbaceous plants to water stress (e.g. Lens et al. 2016) in addition to woody plants that have been featured in most previous investigations.

\section{Correlations among Traits}

Our results for correlations among community-level traits inform understanding of the functional ecology of riparian plant communities. SLA has been suggested to be an axis of variation independent to seed mass and plant mature height 
(Westoby 1998). Significant and moderately strong rank correlations between community SLA and height in both years $\left(r_{s}=-0.62, r_{s}-0.41\right)$ does not support independence of these traits for riparian communities of Grand Canyon, where tall communities generally had low SLA. In contrast, weak correlation between SLA and seed mass in both years $\left(r_{s}=0.04\right.$, $\left.r_{s}=0.11\right)$ is consistent with the hypothesis that these traits are distinct axes of trait variation, with SLA representing leaf investment and physiology, and seed mass representing reproductive strategy. Moderate correlations between SLA and SSG ( $r_{\mathrm{s}}=-0.48$ in $2013, \mathrm{r}_{\mathrm{s}}=-0.27$ in 2014) suggests a general co-occurrence of low-density, hydraulically efficient stems with thin, high-gas-exchange leaves consistent with other studies (Bucci et al. 2004; Maherali et al. 2006; Ishida et al. 2008). This coordination is also a likely driver for the moderate correlation of SSG and height $\left(\mathrm{r}_{\mathrm{s}}=-0.51\right.$ in 2013, $r_{s}=-0.50$ in 2014), with greater community-level height and canopy size requiring greater support and carbon investment in stem tissue. This pattern of correlations among community-level traits is generally similar to our results using species-level means for the same suite of species (McCoySulentic et al. 2017, written communication).

\section{Conclusions}

We learned that communities in more upland, rarely inundated riparian zones had greater plant cover than the frequently inundated active channel zone, which shows limitations on plant establishment and growth by frequent flooding. Communities in more upland zones generally had a suite of traits indicative of drought tolerance (low SLA, high seed mass, high SSG, high coverage by $\mathrm{C} 4$ species) and infrequent disturbance (tall height). All investigated traits (height, seed mass, SLA, SSG) varied in a pattern consistent with a community-level ruderal strategy with adaptation to submergence in frequently inundated plots, and a more drought-tolerant suite of traits in less frequently inundated plots. Variation in community traits not explained by our mixed models, which accounted for spatial sampling variation as well as inundation, suggest niche differentiation and multiple modes of community assembly that may allow coexistence of a range of trait values in a given environment and hence weaken relationships between traits and environmental factors. We found evidence for previously documented independent axes of trait variation between community SLA and seed mass, whereas SLA and height were more dependent than expected (taller communities had lower SLA).

\section{Implications}

Our results provide insight about short term and future riparian plant communities along the Colorado River in Grand Canyon. Lower runoff expected in the future may reduce flow releases from Glen Canyon Dam into the Colorado River leading to lower average river levels and an altered inundation regime in a direction that started decades ago. Reductions in annual peak flood volume and disturbance since 1963 have increased vegetation cover at lower elevations, particularly woody vegetation (Turner and Karpiscak 1980; Gloss et al. 2005; Sankey et al. 2015). Changes in some community traits (e.g., SLA) between the wet year of 2013 and the drier year of 2014 suggest quicker response of some traits to changes in environmental conditions. Total plant cover and traits of SLA and $\mathrm{C} 4$ cover may show faster response to altered hydrologic conditions, whereas other traits such as height, seed mass, and SSG may change more slowly. With further reductions in flow, our results suggest that areas currently in the active channel zone will shift plant communities from dominance by species with high SLA and low SSG, seed mass, height, and cover by $\mathrm{C} 4$ species towards communities having species with traits characteristic of lower inundation tolerance and greater drought tolerance, such as low SLA and high SSG, seed mass and height, and cover by $\mathrm{C} 4$ species. Plant communities in the active floodplain zone may shift toward the drought-tolerant traits of the current inactive floodplain zone, but likely will continue to contain a wide range of trait values because of this zone's intermediate levels of disturbance and stress relative to zones closer and farther from the river.

Acknowledgements We thank the USGS for funding through the WaterSMART program and for providing data and logistical support, and to Grand Canyon National Park for allowing us to work and sample along the Colorado River (Permit\# GRCA-2015-SCI-0015). The manuscript was improved by reviews by Seth Munson (USGS) and Scott Vanderkooi (USGS) and two anonymous reviewers. Roy St. Laurent (Northern Arizona University) provided valuable advice about the statistical analyses. We devote this manuscript to our deceased colleague and co-author Daniel Sarr. Any use of trade, product, or firm names is for descriptive purposes only and does not imply endorsement by the U.S. Government.

Open Access This article is distributed under the terms of the Creative Commons Attribution 4.0 International License (http:// creativecommons.org/licenses/by/4.0/), which permits unrestricted use, distribution, and reproduction in any medium, provided you give appropriate credit to the original author(s) and the source, provide a link to the Creative Commons license, and indicate if changes were made.

\section{References}

Baldwin BG (2002) The Jepson Desert manual: vascular plants of southeastern California. Univ of California Press, Oakland CA

Bernhardt-Römermann M, Römermann C, Nuske R, Parth A, Klotz S, Schmidt W, Stadler J (2008) On the identification of the most suitable traits for plant functional trait analyses. Oikos 117:1533-1541

Boutton TW, Harrison AT, Smith BN (1980) Distribution of biomass of species differing in photosynthetic pathway along an altitudinal transect in southeastern Wyoming grassland. Oecologia 45:287-298

Box GE, Cox DR (1964) An analysis of transformations. Journal of the Royal Statistical Society. Series B (Methodological) 26(2):211-252

Bucci SJ, Goldstein G, Meinzer FC, Scholz FG, Franco AC, Bustamante $M$ (2004) Functional convergence in hydraulic architecture and 
water relations of tropical savanna trees: from leaf to whole plant. Tree Physiology 24:891-899

Chave J, Coomes D, Jansen S, Lewis SL, Swenson NG, Zanne AE (2009) Towards a worldwide wood economics spectrum. Ecology Letters $12: 351-366$

Clark JS (2016) Why species tell more about traits than traits about species: predictive analysis. Ecology 97:1979-1993

Cornwell WK, Ackerly DD (2009) Community assembly and shifts in plant trait distributions across an environmental gradient in coastal California. Ecological Monographs 79:109-126

Cornwell WK, Schwilk DW, Ackerly DD (2006) A trait-based test for habitat filtering: convex hull volume. Ecology 87:1465-1471

Connell JH (1978) Diversity in tropical rain forests and coral reefs. Science 199:1302-1310

Diaz S, Kattge J, Cornelissen JHC, Wright IJ, Lavorel S et al (2016) The global spectrum of plant form and function. Nature 529:167-171

Dolan R, Howard A, Gallenson A (1974) Man's impact on the Colorado River in the grand canyon: the grand canyon is being affected both by the vastly changed Colorado River and by the increased presence of man. American Scientist 62:392-401

Doliner LH, Jolliffe PA (1979) Ecological evidence concerning the adaptive significance of the $\mathrm{C} 4$ dicarboxylic acid pathway of photosynthesis. Oecologia 38:23-34

Dominguez F, Rivera E, Lettenmaier DP, Castro CL (2012) Changes in winter precipitation extremes for the western United States under a warmer climate as simulated by regional climate models. Geophysical Research Letters 39:L05803. doi:10.1029/2011 GL050762

Flora of North America Editorial Committee, eds. (1993)+. Flora of North America North of Mexico. 20+ vols. New York and Oxford

Fraser LH, Garris HW \& Carlyle CN (2016) Predicting plant trait similarity along enviornmental gradients. Plant Ecol 217:1297-1306

Gloss SP, Lovich JE, and Melis TS \& eds (2005) The state of the Colorado river ecosystem in grand canyon. U.S. Geological Survey Circular 1282. 220 p., http://pubs.usgs.gov/circ/1282/

Grime JP (1977) Evidence for the existence of three primary strategies in plants and its relevance to ecological and evolutionary theory. The American Naturalist 111:1169-1194

Grime JP (1979) Plant strategies and ecological processes. Wiley, Chichester

Grubb PJ (1977) The maintenance of species-richness in plant communities: the importance of the regeneration niche. Biological Reviews 52:107-145

Guo Q, Brown JH, Valone TJ, Kachman SD (2000) Constraints of seed size on plant distribution and abundance. Ecology 81:2149-2155

Hacke UG, Sperry JS, Pockman WT, Davis SD, McCulloh KA (2001) Trends in wood density and structure are linked to prevention of xylem implosion by negative pressure. Oecologia 126:457-461

Hampe A (2004) Extensive hydrochory uncouples spatiotemporal patterns of seedfall and seedling recruitment in a 'birddispersed'riparian tree. Journal of Ecology 92:797-807

Hayhoe K, Cayan D, Field CB, Frumhoff PC, Maurer EP, Miller NL, Moser SC, Schneider SH, Cahill KN, Cleland EE, Dale L, Drapek R, Hanemann RM, Kalkstein LS, Lenihan J, Lunch CK, Neilson RP, Sheridan SC, Verville JH (2004) Emissions pathways, climate change, and impacts on California. Proceedings of the National Academy of Sciences of the United States of America 101:12422 12427

Hazel JE, Kaplinsk, M, Parnell R, Kohl K \& Topping DJ (2007) Stagedischarge relations for the Colorado river in Glen, marble, and grand canyons, Arizona, 1990-2005. (No. 2006-1243). Geological Survey (US). http://pubs.usgs.gov/of/2006/1243/pdf/of061243 508.pdf

Hollingsworth TN, Johnstone JF, Bernhardt EL, Chapin FS III (2013) Fire severity filters regeneration traits to shape community assembly in Alaska's boreal forest. PLoS One 8:e56033
Hough-Snee N, Laub BG, Merritt DM, Long AL, Nackley LL, Roper BB, Wheaton JM (2015) Multi-scale environmental filters and niche partitioning govern the distributions of riparian vegetation guilds. Ecosphere 6:1-22

Howard A, Dolan R (1981) Geomorphology of the Colorado River in the grand canyon. Journal Geology 89:269-298

Huisinga K, Makarick L, Watters K (2006) River and desert plants of the grand canyon. Mountain Press Publishing Company, Missoula, MT

Ishida A, Nakano T, Yazaki K, Matsuki S, Koike N, Lauenstein DL, Shimizu M, Yamashita N (2008) Coordination between leaf and stem traits related to leaf carbon gain and hydraulics across 32 drought-tolerant angiosperms. Oecologia 156:193-202

JMP®, Version Pro 13. SAS Institute Inc., Cary, NC

Kazakou E, Violle C, Roumet C, Navas M, Vile D, Kattge J, Garnier E (2014) Are trait-based species rankings consistent across data sets and spatial scales? Journal of Vegetation Science 25:235-247

Kemp PR (1983) Phenological patterns of Chihuahuan Desert plants in relation to the timing of water availability. Journal of Ecology 1: $427-436$

Kyle G, Leishman MR (2009) Plant functional trait variation in relation to riparian geomorphology: the importance of disturbance. Austral Ecology 34:793-804

Larios E, Búrquez A, Becerra JX, Lawrence Venable D (2014) Natural selection on seed size through the life cycle of a desert annual plant. Ecology 95:3213-3220

Lavorel S, Garnier E (2002) Predicting changes in community composition and ecosystem functioning from plant traits: revisiting the holy grail. Functional Ecology 16:545-556

Leishman MR, Westoby M, Jurad E (1995) Correlates of seed size variation: a comparison among five temperate floras. Journal of Ecology 83:517-529

Lens F, Picon-Cochard C, Delmas CEL, Signarbieux C, Buttler A, Cochard H, Jansen S, Chauvin T, Doria LC, del Arco M, Delzon S (2016) Herbaceous angiosperms are not more vulnerable to droughtinduced embolism than angiosperm trees. Plant Physiology. doi:10.1104/pp.16.00829

Lytle DA, Poff NL (2004) Adaptation to natural flow regimes. Trends in Ecology and Evolution 19:94-100

Magirl CS, Breedlove MJ, Webb RH, \& Griffiths PG. (2008) Modeling water-surface elevations and virtual shorelines for the Colorado river in grand canyon, Arizona: U.S. Geological Survey Scientific Investigations Report 2008-5075, 32 p., http://pubs.usgs. gov/sir/2008/5075.

Maherali H, Moura CF, Caldeira MC, Willson CJ, Jackson RB (2006) Functional coordination between leaf gas exchange and vulnerability to xylem cavitation in temperate forest trees. Plant, Cell and Environment 29:571-583

McCoy-Sulentic ME, Kolb TE \& Palmquist EC (2017) Community-level riparian plant traits, Colorado river, grand canyon, 2013-2015 Data: U.S. Geological Survey data release, doi:10.5066/F73R0R24.

McLaughlin SP (1986) Floristic analysis of the southwestern United States. Great Basin Naturalist 46(1):46-65

Merritt D, Bateman HL (2012) Linking stream flow and groundwater to avian habitat in a desert riparian system. Ecological Applications 22: 1973-1988

Merritt DM, Scott ML, Poff LN, Auble GT, Lytle DA (2010) Theory, methods and tools for determining environmental flows for riparian vegetation: riparian vegetation-flow response guilds. Freshwater Biology 55:206-225

Messier J, McGill BJ, Lechowicz MJ (2010) How do traits vary across ecological scales? A case for trait-based ecology. Ecology Letters 13:838-848

Mommer L, Wolters-Arts M, Andersen C, Visser EJW, Pedersen O (2007) Submergence-induced leaf acclimation in terrestrial species varying in flooding tolerance. The New Phytologist 176:337-345 
Naiman RJ, Decamps H, Pollock M (1993) The role of riparian corridors in maintaining regional biodiversity. Ecological Applications 3: 209-212

Nilsson C, Svedmark M (2002) Basic principles and ecological consequences of changing water regimes: riparian plant communities. Environmental Management 30:468-480

Ordonez A (2014) Global meta-analysis of trait consistency of non-native plants between their native and introduced areas. Global Ecology and Biogeography 23:264-273

Palmquist EC, Ralston BE, Sarr D, Merritt D, Shafroth PB, Scott JA (2017) Functional traits and ecological affinities of riparian plants along the Colorado River in grand canyon. Western North American Naturalist 77:22-30

Pérez-Harguindeguy N, Díaz S, Garnier E, Lavorel S, Poorter H, Jaureguiberry P, Bret-Harte MS, Cornwell WK, Craine JM, Gurvich DE (2013) New handbook for standardised measurement of plant functional traits worldwide. Australian Journal of Botany 61:167-234

Pockman WT, Sperry JS (2000) Vulnerability to xylem cavitation and the distribution of Sonoran Desert vegetation. American Journal of Botany 87:1287-1299

Poorter L, Bongers F (2006) Leaf traits are good predictors of plant performance across 53 rain forest species. Ecology 87:1733-1743

Preston KA, Cornwell WK, DeNoyer JL (2006) Wood density and vessel traits as distinct correlates of ecological strategy in 51 California coast range angiosperms. The New Phytologist 170:807-818

Pywell RF, Bullock JM, Roy DB, Warman LIZ, Walker KJ, Rothery P (2003) Plant traits as predictors of performance in ecological restoration. Journal of Applied Ecology 40:65-77

Ralston BE, Starfield AM, Black RS \& Van Lonkhuyzen RA (2014) State-and-transition prototype model of riparian vegetation downstream of Glen Canyon Dam, Arizona. No. 2014-1095. US Geological Survey. doi:10.3133/ofr20141095.

Reich PB (2014) The worldwide 'fast-slow' plant economics spectrum: a traits manifesto. Journal of Ecology 102:275-301

Royal Botanic Gardens Kew. (2016) Seed Information Database (SID). Version 7.1. Available from: http://data.kew.org/sid/ (August 2016)

Sage RF (2004) The evolution of C4 photosynthesis. The New Phytologist 161:41-370

Sandel B, Corbin JD, Krupa M (2011) Using plant functional traits to guide restoration: a case study in California coastal grassland. Ecosphere 2:1-16

Sankey JB, Ralston BE, Grams PE, Schmidt JC, Cagney LE (2015) Riparian vegetation, Colorado River, and climate: five decades of spatiotemporal dynamics in the grand canyon with river regulation. Journal of Geophysical Research: Biogeosciences 120:1532-1547

Schmidt JC (1990) Recirculating flow and sedimentation in the Colorado River in grand canyon, Arizona. Journal of Geology 98:709-724

Seager R, Vecchi GA (2010) Greenhouse warming and the 21st century hydroclimate of southwestern North America. Proceedings of the National Academy of Sciences of the United States of America 107:21277-21282

Seager R, Ting M, Held I, Kushnir Y, Lu J, Vecchi G, Huang HP, Harnik N, Leetmaa A, Lau NC, Li C, Velez J, Naik N (2007) Model projections of an imminent transition to a more arid climate in southwestern North America. Science 316:1181-1184

Shafroth PB, Stromberg JC, Patten DT (2002) Riparian vegetation response to altered disturbance and stress regimes. Ecological Applications 12:107-123

Shipley B, De Bello F, Cornelissen JHC, Laliberté E, Laughlin DC, Reich PB (2016) Reinforcing loose foundation stones in trait-based plant ecology. Oecologia 180:923-931

Sluis W, Tandarich J (2004) Siltation and hydrologic regime determine species composition in herbaceous floodplain communities. Plant Ecology 173:115-124
Sorrell BK, Mendelssohn IA, McKee KL, Woods RA (2000) Ecophysiology of wetland plant roots: a modelling comparison of aeration in relation to species distribution. Annals of Botany 86:675-685

Stevens LE, Schmidt JC, Ayers TJ, Brown BT (1995) Flow regulation, geomorphology, and Colorado River marsh development in the grand canyon, Arizona. Ecological Applications 5:1025-1039

Stromberg JC (2013) Root patterns and hydrogeomorphic niches of riparian plants in the American southwest. Journal of Arid Environments 94:1-9

Stromberg JC, Beauchamp VB, Dixon MD, Lite SJ, Paradzick C (2007) Importance of low-flow and high-flow characteristics to restoration of riparian vegetation along rivers in arid South-Western United States. Freshwater Biology 52:651-679

Stromberg JC, Boudell JA, Hazelton AF (2008) Differences in seed mass between hydric and xeric plants influence seed bank dynamics in a dryland riparian ecosystem. Functional Ecology 22:205-212

Swenson NG, Weiser MD (2010) Plant geography upon the basis of functional traits: an example from eastern north American trees. Ecology 91:2234-2241

Syvertsen JP, Nickell GL, Spellenberg RW, Cunningham GL (1976) Carbon reduction pathways and standing crop in three Chihuahuan Desert plant communities. The Southwestern Naturalist 21:311-320

Teeri JA, Stowe LG (1976) Climatic patterns and the distribution of C4 grasses in North America. Oecologia 23:1-12

Topping DJ, Schmidt JC, \& Vierra LE (2003). Computation and analysis of the instantaneous-discharge record for the Colorado River at Lees Ferry, Arizona: May 8, 1921, through September 30, 2000 (p. 118). US Geological Survey Professional Paper 1677. http://pubs.usgs. gov/pp/pp1677/pdf/pp1677.pdf.

Turner RM, Karpiscak MM (1980) Recent vegetation changes along the Colorado River between Glen canyon dam and Lake mead. Arizona, US Geological Survey Report

U.S Department of the Interior (1996) Record of Decision, Operation of Glen Canyon Dam: Final Environmental Impact Statement, pp15, Office of the Secretary of the Interior. Bureau of Reclamation, Washington, D.C. http://www.usbr.gov/uc/rm/amp/pdfs/sp_ appndxG_ROD.pdf

Voesenek L, Colmer TD, Pierik R, Millenaar FF, Peeters AJM (2006) How plants cope with complete submergence. The New Phytologist 170:213-226

Wahl S, Ryer P (2000) Root tissue structure is linked to ecological strategies of grasses. The New Phytologist 148:459-471

Waller SS, Lewis JK (1979) Occurrence of C3 and C4 photosynthetic pathways in north American grasses. Journal of Range Management $1: 12-28$

Weiher E, Werk A, Thompson K, Roderick M, Garnier E \& Eriksson O (1999) Challenging Theophrastus: a common core list of plant traits for functional ecology. J Veg Sci 10:609-620

Welsh SL, Atwood ND, Goodrich S, Higgins LC (2003) A Utah Flora Monte Bean Life Science Museum, Provo, UT

Westoby M (1998) A leaf-height-seed (LHS) plant ecology strategy scheme. Plant and Soil 199:213-227

Westoby M, Wright IJ (2006) Land-plant ecology on the basis of functional traits. Trends in Ecology and Evolution 21:261-268

Westoby M, Jurado E, Leishman M (1992) Comparative evolutionary ecology of seed size. Trends in Ecology and Evolution 7:368-372

Williamson GB, Wiemann MC (2010) Measuring wood specific gravity...Correctly. American Journal of Botany 97:519-524

Wright IJ, Reich PB, Westoby M, Ackerly DD, Baruch Z, Bongers F, Cavender-Bares J, Chapin T, Cornelissen JHC, Diemer M, Flexas J, Garnier E, Groom PK, Gulias J, Hikosaka K, Lamont BB, Lee T, Lee W, Lusk C, Midgley JJ (2004) The worldwide leaf economics spectrum. Nature 428:821-827 